\title{
Microbial Infections as an Etiology of Behcet's Disease
}

\author{
Rasha H. Bassyouni ${ }^{1}$, Ahmed Ashraf Wegdan ${ }^{1}$, Roba M Talaat ${ }^{2}$, \\ A. Abdelmoktader ${ }^{1}$ and Iman $\mathbf{H}$ Bassyouni $^{3}$ \\ ${ }^{1}$ Medical Microbiology and Immunology Department, Faculty of Medicine, \\ Fayoum University, Fayoum, Egypt \\ ${ }^{2}$ Molecular Biology Department, Genetic Engineering and Biotechnology \\ Research Institute (GEBRI), Sadat City University, Sadat City, Egypt \\ ${ }^{3}$ Rheumatology and Rehabilitation Department, Faculty of Medicine, \\ Cairo University, Cairo, Egypt \\ *Corresponding author
}

\section{A B S T R A C T}

\begin{tabular}{|l|}
\hline Ke y w o r d s \\
Behçet's disease, \\
Bacteria; Virus, \\
Heat shock proteins. \\
\hline Article Info \\
\hline $\begin{array}{l}\text { Accepted: } \\
\text { 24 January } 2017 \\
\text { Available Online: } \\
\text { 10 February } 2017\end{array}$ \\
\hline
\end{tabular}

Keywords

Behçet's disease, Bacteria; Virus, Heat shock proteins.

\section{Introduction}

Behçet's disease (BD) is considered a chronic relapsing multisystem inflammatory disorder characterized by four major symptoms (genital ulcers, oral aphthous ulcers, ocular lesions and skin lesions) and occasionally by five minor symptoms (arthritis, epididymitis, gastrointestinal ulcers, vascular lesions, and central nervous system) (Cho et al., 2012). $\mathrm{BD}$ has a worldwide distribution, but it is more prevalent in the regions along the ancient trading route known as "Silk Road," extending from Mediterranean countries such as Turkey to the Far East including Korea and Japan. The prevalence of BD in Turkey is particularly high at $80-420 / 100,000$ (Azizlerli et al., 2003). In Egypt the prevalence is at 7.6/100,000 Skef et al., 2015). BD starts in the third and fourth decade of life and runs a more severe course in men and in those with a younger age of onset (Gül, 2005).

Although its etiopathogenesis remains elusive, the most accepted hypothesis is that the excessive inflammatory response is triggered by an infectious agent in a genetically susceptible host (Hamedi et al., 2014). 
When an infectious etiology for $\mathrm{BD}$ was pondered initially, researchers were trying to identify an organism that causes BD and fulfils Koch's postulates (four criteria designed to establish a relationship between a causative microbe and a disease). Attempts were made to isolate the microorganism from lesions and from sera of BD patients inoculated into animals, aiming to induce BD. Later, as the concept of micro-organisms causing autoimmune and inflammatory diseases through regulation of the immune response was developed, studies were changed trying to understand the changes in the cytokine profile, the role of $\mathrm{T}$-cell hypersensitivity and heat shock proteins (HSPs) (Hatemi, 2011).

Clinical studies showed the efficacy of penicillin on mucocutaneous and joint lesions of BD (Erkan et al., 2012) and there has been a decrease in the frequency of a positive pathergy reaction with surgical cleaning of the skin before the procedure (Cheon et al., 2010). The skin, oral mucosa and the gastrointestinal mucosa are the main sites that encounter microorganisms as they are entering the body. The presence of an increased proportion of certain streptococcal strains in the oral flora and the isolation of a virus in certain BD lesions have led to search on the role of viruses and bacteria in the aetiopathogenesis of BD (Hatemi, Yazici 2011).

\section{Viruses}

In 1937, Behçet had suggested that a virus may cause the disease upon the observation of intracellular inclusion-like forms in smears from the hypopyon of the anterior chamber and from oral ulcers. However, he was unable to isolate the putative virus (Behcet, 1937). Years later, a virus was isolated from the ocular fluid of BD patients, which caused symptoms somewhat resembling $\mathrm{BD}$ when inoculated into mice and rabbits (Yildirim, 2012). Subsequently, a virus was isolated from the eye and brain tissues of a BD patient who died with neurologic involvement. However, these results could not be confirmed later Hatemi, 2011).

A number of viruses, including hepatitis viruses, parvovirus B19, and herpes simplex virus (HSV) have been implicated in the etiology of BD. However, only evidence with regard to $\mathrm{HSV}$ is found to be suggestive of a possible link. HSV-1 genome and serum antibodies against the virus have been found in a higher proportion of patients with BD than in controls (Pay et al., 2007) HSV DNA can be detected in the genital and oral ulcers of patients with BD (Tojo et al., 2007). Furthermore, inoculation of HSV into the mice has been shown to cause lesions mimicking BD (Un et al., 2007).

\section{Bacteria}

Most investigated microorganisms related to the etiology of BD are Streptococci e.g. Streptococcus sanguis, Streptococcus mitis, $S$. faecalis and Streptococcus salivarius. Streptococci identification was based on frequent nasopharyngeal infections, dental caries, and other foci of streptococcal infection. The symptoms present at the onset of the disease and high frequency characterizes by oral aphthous ulcers (Galeone et al., 2012); (Dabbagh et al., 2014).

As BD starts mostly from the oral mucosal surface, oral microbial flora have long been implicated in the pathogenesis. Patients with BD generally have a very high incidence of chronic Streptococcal infections as tonsillitis and dental caries in the oral cavity, and the hyper-reactivity to Streptococcal antigens might be related to these chronic infection foci (Dabbagh et al., 2014). S. sanguis correlates to dental caries, periodontal 
infections and a high number of colonies in oral flora. Furthermore, in mice free of bacteria after oral trauma, S. sanguis induces oral and ocular infections similar to BD (Isogai et al., 2003) S. mitis, S. salivarius and $S$. mutans are also associated with frequent oral infections and pro-inflammatory mediator's release(Zouboulis and May, 2003).

Aggravation of the symptoms during dental infection treatment has also been noticed. Treatment of dental and periodontal infections stimulates oral ulcers for a short period of time, even though treatment of chronic oral infections ameliorates the prognosis in BD patients for a long period of time (Dabbagh et al., 2014).

Systemic BD symptoms have also been reported one to two weeks after contact with Gram negative bacilli as Escherichia coli and Klebsiella pneumonia (Dabbagh et al., 2014).

\section{Heat shock proteins}

These proteins are synthesized when eukaryotic and prokaryotic cells are exposed to various nonspecific stimuli (infection, trauma, heat, hypoxia, and cold) and protect cells from severe damage and premature death by preventing denaturation and degradation of cellular proteins. They have highly conserved amino acids sequence. There is sequence homology between HSP65 in bacteria, and human mitochondrial HSP60 (Kapsimali et al., 2010).

Antibodies against the streptococcal HSP60 were found in BD. A statistically significant increase in the expression of HSP60/65 was noted in patients with active BD and mucocutaneous ulcers compared to controls (Ergun et al., 2001) Moreover, four peptides from $65-\mathrm{kDa}$ mycobacterial HSP and their homologous peptides from human $60 \mathrm{kDa}$, stimulate proliferation of $\gamma \delta+\mathrm{T}$-cells in $\mathrm{BD}$ patients (Direskeneli et al., 2013) Both $\mathrm{T}$ $(\alpha \beta+$ and $\gamma \delta+)$ and B lymphocytes-mediated immune responses participate in the development of ophthalmic and mucocutaneous lesions according to the following observations: first, antibodies against bacterial and human HSP60/65 cross react to specific retinal antigens. Second, local skin lesions in BD patients are characterized by high levels of $\gamma \delta+\mathrm{T}$-cell receptor and HSP60. Third, $\gamma \delta+\mathrm{T}$ lymphocytes are detected in tissue, while HSP65 is notably increased in erythema nodosum and mucocutaneous ulcers. Fourth, Increased HSP levels induce the expression of the Major Histocompatibility Complex class I chain-related gene A (MICA) region (Direskeneli and Saruhan, 2003).

Administration of HSP peptides to the mice via subcutaneous route has been shown to induce uveitis without causing other features related with BD (Pay et al., 2007). Likewise, oral administration of these peptides induced clinical uveitis in experimental rats (Mayer and Shao, 2004). Another interesting study showed increase in the $S$. sanguis colonization with the subsequent development of uveitis in rats exposed to heat shock. These observations may reflect the important role of stress both in the breakdown of mucosal defenses and anti-HSP reactivity (Isogai, et al., 2003).

In conclusion microorganisms could trigger or actively participate in the pathophysiology of BD. Identifying the microbial role in BD may facilitate more effective management and preventive therapies for this disease.

\section{References}

Cheon, J.H., Çelik, A.F., Kim, W.H. 2010. Behçet's disease: Gastrointestinal involvement. In: Yazici Y, Yazici H, editors. Behçet's syndrome. New York: Springer; 165-89. 
Erkan, A., Ayse, A. 2006. Treatment of Behçet's disease. Ther., 3(1): 139-151.

Hatemi, G., Yazici, H. 2011. Behçet's syndrome and micro-organisms. Best Pract. Res. Clin. Rheumatol., 25: 389-406.

Mayer, L., Shao, L. 2004. Therapeutic potential of oral tolerance. Nature Reviews Immunol., 4: 407-419.

Azizlerli, G., Ko“se, A.A., Sarica, R., Gül, A., Tutkun, I.T., Kulaç, M., Tunç, R., Urgancioğlu, M., Dişçi, R. 2003. Prevalence of Behc, et's disease in Istanbul, Turkey. Int. J. Dermatol., 42: 803-806.

Behcet, H. 1937. U“" ber rezidivierende, aphtho“ se, durch ein virus verursachte Geschwu" re am Mund, am Auge und an den Genitalien. Dermatol. Wochenschr, 105: 1152-7.

Cho, S., Kim, J., Cho, S.B., Zheng, Z., Choi, M.J., Kim, D.Y., Bang, D. 2012. Immunopathogenic characterization of cutaneous inflammation in Behçet's disease. J. European Academy of Dermatol. Venereol., 28(1): 51-57.

Dabbagh, F., Haghighi, A.B., Ghasemi, Y. 2014. Behcet's disease: from heat shock proteins to infections. Asian Biomed., 8(2): 139-155.

Direskeneli, H., Saruhan-Direskeneli, G. 2003. The role of heat shock proteins in Behçet's disease. Clin. Exp. Rheumatol., 21: S44-S48.

Direskeneli, H. 2013. Innate and Adaptive Responses to Heat Shock Proteins in Behcet's Disease. Genetics Res.. Int., 751942: 6.

Ergun, T., Ince, U., Ekşioğlu-Demiralp, E., Direskeneli, H., Gürbüz, O., Gürses, L., Aker, F., Akoğlu, T. 2002. HSP60 expression in mucocutaneous lesions of Behçet's disease. $J$. Am. Acad. Dermatol., 45: 904-909.

Galeone, M., Colucci, R., D'Erme, A.M., Moretti, S., Lotti, T. 2012. Potential Infectious Etiology of Behçet's Disease. Pathol. Res. Int., 1-4.

Gül, A., Karasneh, J., Ollier, W.E., Silman, A.J., Worthington, J. 2005. Whole-genome screening for susceptibility genes in multicase families with Behçet's disease. Arthritis Rheum., 52(6): 1836-42.

Hamedi, M., Bergmeier, L.A., Hagi-Pavli, E., Vartoukian, S.R., Fortune, F. 2014. Differential Expression of Suppressor of Cytokine Signalling Proteins in Behcet's Disease. Scand J. Immunol., 80(5): 369-76.

Isogai, E., Hirata, M,. Isogai, H., Matuo, K., Kimura, K., Yokota, K., Oguma, K., Tojo, M., Kaneko, F., Kotake, S., Ohno, S. 2005. Antimicrobial activity of synthetic human CAP 18 peptides to Streptococcus sanguis isolated from patients with Behcet's disease. Adv. Exp. Med. Biol., 528: 195-200.

Kapsimali, V.D., Kanakis, M.A., Vaiopoulos, G.A., Kaklamanis, P.G. 2010. Etiopathogenesis of Behçet's disease with emphasis on the role of immunological aberrations. Clin. Rheumatol., 29: 1211-1216.

Pay, S., Şimşek, I., Erdem, H., Dinç, A. 2007. Immunopathogenesis of Behçet's disease with special emphasize on the possible, Rheumatol. Int., 27: 417-424.

Skef, W., Hamilton, M.J., Arayssi, T. 2015. Gastrointestinal Behçet's disease. World J. Gastroenterol., 21(13): 3801-3812.

Tojo, M., Zheng, X., Yanagihori, H., Oyama, N., Takahashi, K., Nakamura, K., Kaneko, F. 2003. Detection of Herpes Virus Genomes in Skin Lesions from Patients with Behcet's Disease and Other Related Inflammatory Diseases. Acta Derm. Venereol., 83: 124-127.

Un Chul, P., Kim, T.W., Yu, H.G. 2014. Immunopathogenesis of Ocular Behçet's Disease, J. Immunol. Res., 1- 13.

Yildirim, O. 2012. Animal Models in Behçet's Disease. Patholog. Res. Int., 273701.

Zouboulis, C.C., May, T. 2003. Pathogenesis of Admantiades-Behcet's disease. Med. Microbiol. Immunol., 192: 149-55.

\section{How to cite this article:}

Rasha H. Bassyouni, Ahmed Ashraf Wegdan, Roba M. Talaat, A. Abdelmoktader, Iman H Bassyouni. 2017. Microbial Infections as an Etiology of Behcet's Disease. Int.J.Curr.Microbiol.App.Sci.6(2): 1694-1697. doi: http://dx.doi.org/10.20546/ijcmas.2017.602.189 